\title{
Cisplatin-induced hydroxyl radicals mediate pro-survival autophagy in human lung cancer H460 cells
}

Somruethai Sumkhemthong ${ }^{1}$, Eakachai Prompetchara ${ }^{2,3}$, Pithi Chanvorachote ${ }^{4,5^{*}}$ and Chatchai Chaotham ${ }^{1,5^{*}}$ (1)

\begin{abstract}
Background: Accumulated evidence demonstrates cisplatin, a recommended chemotherapy, modulating pro-survival autophagic response that contributes to treatment failure in lung cancer patients. However, distinct mechanisms involved in cisplatin-induced autophagy in human lung cancer cells are still unclear.

Results: Herein, role of autophagy in cisplatin resistance was indicated by a decreased cell viability and increased apoptosis in lung cancer $\mathrm{H} 460$ cells pre-incubated with wortmannin, an autophagy inhibitor, prior to treatment with $50 \mu \mathrm{M}$ cisplatin for $24 \mathrm{~h}$. The elevated level of hydroxyl radicals detected via flow-cytometry corresponded to autophagic response, as evidenced by the formation of autophagosomes and autolysosomes in cisplatin-treated cells. Interestingly, apoptosis resistance, autophagosome formation, and the alteration of the autophagic markers, LC3-II/LC3-I and p62, as well as autophagy-regulating proteins Atg7 and Atg3, induced by cisplatin was abrogated by pretreatment of $\mathrm{H} 460$ cells with deferoxamine, a specific hydroxyl radical scavenger. The modulations in autophagic response were also indicated in the cells treated with hydroxyl radicals generated via Fenton reaction, and likewise inhibited by pretreatment with deferoxamine.
\end{abstract}

Conclusions: In summary, the possible role of hydroxyl radicals as a key mediator in the autophagic response to cisplatin treatment, which was firstly revealed in this study would benefit for the further development of novel therapies for lung cancer.

Keywords: Cisplatin, Autophagy, Drug resistance, Hydroxyl radicals, Lung cancer

\section{Background}

Cancer is a serious non-communicable disease characterized by the overwhelming growth and proliferation of tumor cells [1]. Among many types, lung cancer contributes the highest incidence and mortality rate in both male and female patients worldwide [2]. Despite the availability of advance therapies, including surgery, radiation, and

\footnotetext{
*Correspondence: pithi_chan@yahoo.com; cchoatham@gmail.com

${ }^{1}$ Department of Biochemistry and Microbiology, Faculty

of Pharmaceutical Sciences, Chulalongkorn University, 10330 Bangkok, Thailand

${ }^{4}$ Department of Pharmacology and Physiology, Faculty of Pharmaceutical Sciences, Chulalongkorn University, 10330 Bangkok, Thailand

Full list of author information is available at the end of the article
}

chemotherapy, the success of lung cancer treatments remains regressive [3]. The combined therapy between anticancer drugs with another treatment has been recommended for lung cancer patients at an advanced stage in order to prolong their survival and improve their quality of life [4]. Nevertheless, the incidence of chemotherapeutic failure and relapse of tumor pathology is continuously being documented. The limited response or resistance to current anticancer drugs is a critical factor that influences treatment failure in lung cancer [5].

Cisplatin is an alkylating agent that has been approved for the treatment of ovarian, bladder, and lung cancers [6]. However, accumulated evidence reveals the resistance to this platinum-containing drug, especially in lung 
cancer [7-11]. The modulation of apoptosis-regulating proteins is wildly accepted as a major molecular mechanism associated with chemo-resistance. Recently, considerable attention has been paid to the pro-survival autophagic response mediated in cancer cells after exposure to anticancer drugs [12-14]. Although a protective effect of autophagy against cisplatin induced-toxicity has been reported in various cancers, the regulating machinery involved in the autophagic response in cisplatin treated-human lung cancer cells is still unclear $[13,15$, 16].

Autophagy is a stress response that conserves homeostasis against environmental changes by recycling cellular components and generating new energy inside the cell [17]. Additionally, autophagy plays an important role in chemotherapeutic resistance in various cancer cells [15-17]. Cancer cells derived from cisplatin treatment highly express an autophagy-regulating protein, Beclin-1, which facilitates the conversion of microtubule-associated protein 1 light chain 3 (LC3-I) to the phosphatidylethanolamine conjugated form (LC3-II), a marker of autophagosome formation [18]. Orchestrate signaling of autophagy begins with the activation of Beclin-1 to initiate the formation of phagophore, a double membrane component, followed by the conjugation between the autophagy-related protein (Atg) 12 and Atg5 [19]. To expand the double membrane and construct the autophagosome vesicle, which sequesters damaged cellular organelles/molecules, the Atg12-Atg5 complex together with Atg3 and Atg7 further converts LC3-I to LC3-II. The LC3-II then interacts with p62 (sequestosome 1), an autophagy substrate. Recycling of degraded products from damaged organelles/molecules occurs in the autolysosome vesicle, which arises from the fusion between an autophagosome and a lysosome [20-22].

Various stress stimuli, such as nutrient deprivation, reactive oxygen species (ROS), and damaged proteins/organelles, can activate the autophagic cascade [12]. Because not only DNA damage but also oxidative stress can be generated by cisplatin, the present study aimed to investigate the role of ROS on the pro-survival autophagic response in cisplatin-treated human lung cancer cells. The information gained from this study should enhance the understanding of cisplatin-resistance mechanism and shed light on the further development of an effective chemotherapy for treatment of lung cancer.

\section{Results}

\section{Cytotoxicity of cisplatin to human lung cancer cells}

To clarify the anticancer activity of cisplatin in human lung cancer cells, the relative viability of human lung cancer H460 cells treated with cisplatin at various concentrations was determined via MTT assay. After culture with Roswell Park Memorial Institute (RPMI) medium containing $0-100 \mu \mathrm{M}$ cisplatin for $24 \mathrm{~h}$, a concentration-dependent reduction in the relative cell viability was observed in the cells incubated with cisplatin at 10-50 $\mu \mathrm{M}$ (Fig. 1a). However, the viability did not further decrease but remained constant at about $40 \%$ with the higher cisplatin concentration $(100 \mu \mathrm{M})$. Mode of cell death was evaluated through nuclear staining assay. Treatment for $24 \mathrm{~h}$ with $50 \mu \mathrm{M}$ Actinomycin D and 500 $\mu \mathrm{M}$ hydrogen peroxide $\left(\mathrm{H}_{2} \mathrm{O}_{2}\right)$ was respectively used as a positive control for inducing apoptosis and necrosis [23]. Hoechst33342/propidium iodide (PI) costaining demonstrated the presence of apoptotic cells indicating bright blue Hoechst33342 fluorescence of condensed DNA/ fragmented nuclei, but not necrotic cells stained with red PI fluorescence, in response to the treatment of $\mathrm{H} 460$ cells either with cisplatin $(25-100 \mu \mathrm{M})$ or Actinomycin D $(50 \mu \mathrm{M})$ for $24 \mathrm{~h}$ (Fig. 1c). In accord with the MTT viability assay, comparable levels of apoptosis were induced by cisplatin at 50 and $100 \mu \mathrm{M}$ (Fig. 1b). Therefore, $50 \mu \mathrm{M}$ cisplatin was the lowest concentration that exhibited the maximum cytotoxic activity and was selected for further investigation of the drug resistance mechanisms in human lung cancer cells.

\section{Cisplatin induces an autophagic response in lung cancer H460 cells}

To investigate the autophagic response, the alteration of autophagy marker proteins was evaluated in H460 cells cultured with $50 \mu \mathrm{M}$ cisplatin at various time points $(0-12 \mathrm{~h})$. Although western blot analysis revealed a noticeable conversion from LC3-I to LC3-II after $12 \mathrm{~h}$ (Fig. 2a), the decreased level of the autophagy substrate, p62, was evident earlier at $6 \mathrm{~h}$ of cisplatin treatment (Fig. 2b). Additionally, cisplatin-treated $\mathrm{H} 460$ cells were stained with monodansylcadaverine (MDC) in order to evaluate autophagosome formation. Corresponding to the expression level of LC3-II/LC3-I, a slight detection of MDC-labeled vacuoles was indicated in H460 cells cultured with $50 \mu \mathrm{M}$ cisplatin for 3-9 h and was then strongly observed at $12 \mathrm{~h}$ of cisplatin treatment (Fig. 2c). From the different fluorescence color of acridine orange at an acidic and neutral $\mathrm{pH}$, the fusion of a lysosome and autophagosome, which results in acidic autolysosome, can be illustrated with red fluorescence of acridine orange [24]. As demonstrated in Fig. 2c, an accumulation of acidic vacuoles was gradually observed in $\mathrm{H} 460$ cells after 6-12 h of the incubation with $50 \mu \mathrm{M}$ cisplatin. Taken together, these results demonstrated that cisplatin induced an autophagic response in human lung cancer cells in a time-dependent manner.

The underlying mechanisms of cisplatin-induced autophagy in human lung cancer cells were further 

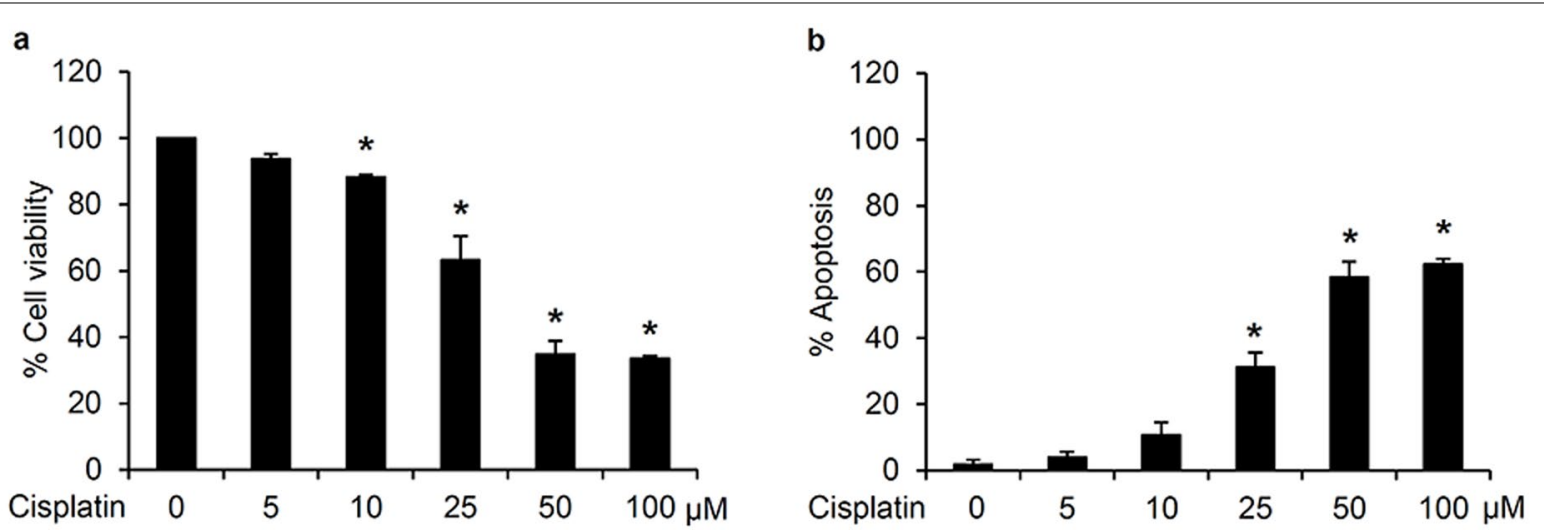

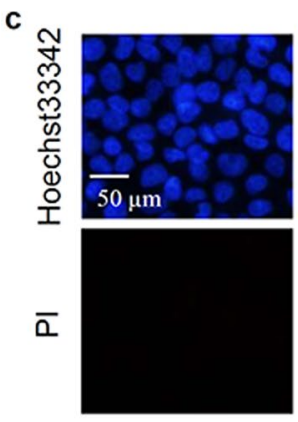

0
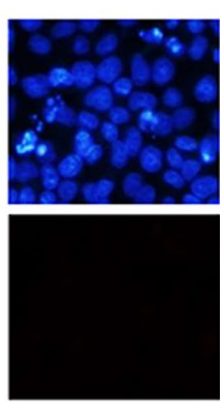

10
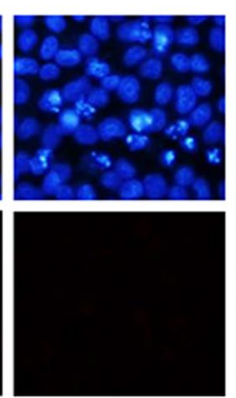

25
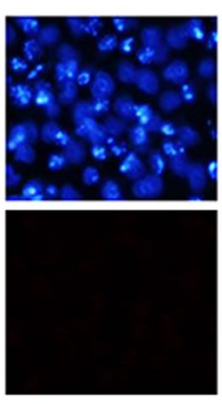

50
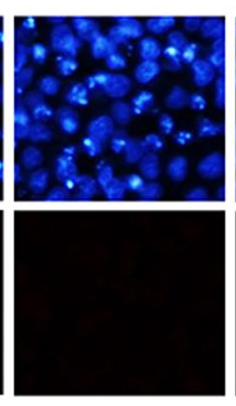

100

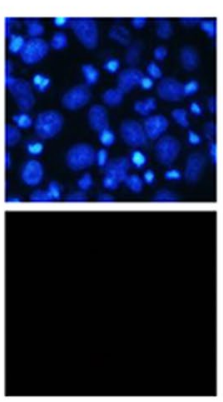

Actinomycin D

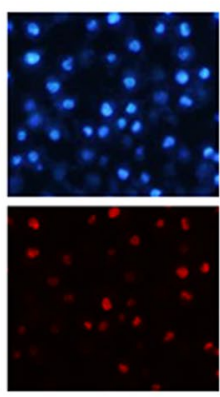

$\mathrm{H}_{2} \mathrm{O}_{2}$ $500 \mu \mathrm{M}$

Fig. 1 Cisplatin-induced cytotoxicity in human lung cancer cells. a MTT assay revealed the significant reduction in the relative cell viability in lung cancer $\mathrm{H} 460$ cells after treatment with 10-100 $\mathrm{\mu M}$ cisplatin for $24 \mathrm{~h}$. b Increased level of apoptosis was noted after culturing with cisplatin at 25-100 $\mu \mathrm{M}$. c Bright blue fluorescence of Hoechst33342, representing apoptosis, was clearly observed in H460 cells after treatment with cisplatin (25-100 $\mu \mathrm{M})$ for $24 \mathrm{~h}$, while there was no detectable necrosis (red fluorescence of propidium iodide; PI). Actinomycin D (50 $\mu \mathrm{M}$ ) and hydrogen peroxide $\left(\mathrm{H}_{2} \mathrm{O}_{2}\right)$ at $500 \mu \mathrm{M}$ was used as a positive control for inducing apoptosis and necrosis, respectively. Data are shown as the $\operatorname{mean} \pm \operatorname{SD}(n=3)$. ${ }^{*} p<0.05$ versus untreated control cells

elucidated. Figure 2d indicates the overexpression of Atg3 and Atg7, the regulatory proteins converting LC3-I to LC3-II, in H460 cells cultured with $50 \mu \mathrm{M}$ cisplatin for $12 \mathrm{~h}$, which correlated well with the higher expression level of LC3-II/LC3-I at $12 \mathrm{~h}$ of cisplatin treatment (Fig. 2a and b). However, the alteration of the other autophagy-regulating proteins (Atg5, Atg12, and Beclin-1) was not significantly detected in human lung cancer cells cultured with $50 \mu \mathrm{M}$ cisplatin compared to those non-treated control cells (Fig. 2e).

\section{Autophagy mediates cisplatin resistance in human lung cancer cells}

Because the influence of autophagy on chemo-resistance has been frequently reported $[13,15,16]$, the protective role of the autophagic response against cisplatin induced-cell death in human lung cancer cells was further confirmed in this study. Lung cancer H460 cells were pre-incubated with either $0.5 \mu \mathrm{M}$ wortmannin (an autophagy inhibitor) or $100 \mathrm{nM}$ rapamycin (an autophagy stimulator) for $30 \mathrm{~min}$ prior to exposure to $50 \mu \mathrm{M}$ cisplatin. After $24 \mathrm{~h}$ of cisplatin treatment, the relative cell viability (Fig. 3a) and level of apoptosis (Fig. 3b) were significantly different in both types of pretreated $\mathrm{H} 460$ cells compared with the cells cultured only with cisplatin. As shown in Fig. 3c, pretreatment with the autophagy inhibitor, wortmannin, augmented the level of apoptosis, as evidenced by the condensed DNA and/or fragmented nuclei in H460 cells cultured with $50 \mu \mathrm{M}$ cisplatin for $24 \mathrm{~h}$. Intriguingly, rapamycin, an autophagy activator, restrained the level of apoptosis in cisplatin-treated H460 cells. These results support the pro-survival role of autophagy on cisplatin resistance in human lung cancer cells. 


\section{Role of hydroxyl radicals on regulation of the autophagic response in cisplatin-treated $\mathrm{H} 460$ cells}

A relationship between intracellular ROS levels and chemotherapeutic resistance has already been documented [25-27]. Moreover, cisplatin has been reported to induce oxidative stress in various cell types [28-30]. Accordingly, the generation of cellular ROS in response to cisplatin treatment of $\mathrm{H} 460$ cells was examined in this study. Human lung cancer $\mathrm{H} 460$ cells were incubated with $50 \mu \mathrm{M}$ cisplatin for $0-6 \mathrm{~h}$ and then the level of cellular ROS was primary assessed through flow cytometry analysis of the non-specific fluorescence probe, $2^{\prime}, 7^{\prime}$-dichloro-dihydro-fluorescein diacetate ester $\left(\mathrm{DCFH}_{2}-\mathrm{DA}\right)$, which interacts with all species of ROS. Figure 4a shows the derived increment in the relative ROS level in $\mathrm{H} 460$ cells incubated with cisplatin for 3-6 h. Furthermore, the accumulation of intracellular hydroxyl radicals $\left(\mathrm{OH}^{\prime}\right)$ was detected using the $3^{\prime}$-( $p$-hydroxyphenyl) fluorescein (HPF) fluorescence probe, with the results showing a time-dependent increase in cisplatintreated H460 cells and being markedly increased at $6 \mathrm{~h}$ of cisplatin treatment. The chromatograms obtained from the flow cytometry indicate a corresponding shift in DCF (total ROS) and HPF $\left(\mathrm{OH}^{\circ}\right)$ fluorescence intensity in $\mathrm{H} 460$ cells cultured with cisplatin for $6 \mathrm{~h}$, while there was no noticeable change of the level of superoxide anions $\left(\mathrm{O}_{2}{ }^{-}\right)$, as presented by the dihydroethidium (DHE) intensity (Fig. 4b). The alteration of the intracellular hydrogen peroxide $\left(\mathrm{H}_{2} \mathrm{O}_{2}\right)$ level in lung cancer cells cultured with $50 \mu \mathrm{M}$ cisplatin was determined using the Amplex ${ }^{\circledR}$ Red Hydrogen Peroxide/Peroxidase Assay kit (Life Technologies, Eugene, OR, USA). Incubation with $500 \mu \mathrm{M} \mathrm{H}_{2} \mathrm{O}_{2}$ for $1 \mathrm{~h}$ rapidly increased the relative $\mathrm{H}_{2} \mathrm{O}_{2}$ level (Fig. 4c), as a positive control, whereas with $50 \mu \mathrm{M}$ cisplatin for 1-6 h did not significantly elevate $\mathrm{H}_{2} \mathrm{O}_{2}$ production in these $\mathrm{H} 460$ cells. Thus, most if not all of the ROS formed in cisplatin-treated $\mathrm{H} 460$ cells were $\mathrm{OH}$.

To provide supportive information regarding the role of $\mathrm{OH}^{\prime}$ on the cisplatin-mediated autophagic response, lung cancer $\mathrm{H} 460$ cells were pretreated with deferoxamine, a $\mathrm{OH}^{\prime}$ scavenger. After pre-incubation with $1 \mathrm{mM}$ deferoxamine for $30 \mathrm{~min}, \mathrm{H} 460$ cells were washed with PBS to minimize the direct effect of deferoxamine on autophagy modulation $[31,32]$ before being cultured with $50 \mu \mathrm{M}$ cisplatin for $12 \mathrm{~h}$. Pretreatment with deferoxamine significantly suppressed the cisplatin-mediated autophagy, as evidenced by the lower Atg7, Atg3, and LC3-II/LC3-I expression levels in deferoxamine-pretreated $\mathrm{H} 460$ cells compared with the cells cultured only with cisplatin (Fig. 5a). Moreover, there was no alteration of the p62 expression level in $\mathrm{H} 460$ cells pre-incubated with $1 \mathrm{mM}$ deferoxamine prior to cisplatin, compared with the nontreated control cells (Fig. 5b). The data correspond with the MDC and acridine orange fluorescence dye staining, which revealed the inhibitory effect of the $\mathrm{OH}^{\prime}$ scavenger, deferoxamine, on autophagosome and autolysosome formation induced by cisplatin in H460 cells (Fig. 5c).

Furthermore, the modulation on cisplatin sensitivity was also determined in deferoxamine-pretreated lung cancer cells. Similarly, human lung cancer H460 cells were pre-incubated with $1 \mathrm{mM}$ deferoxamine for $30 \mathrm{~min}$ then the cells were washed with PBS to remove excess deferoxamine and prevent the direct survival activity of deferoxamine [31-33]. After further culture with $50 \mu \mathrm{M}$ cisplatin for $24 \mathrm{~h}$, the significant reduction of relative cell viability was presented in deferoxamine-pretreated $\mathrm{H} 460$ cells compared with the cells only treated with cisplatin (Fig. 6a). Moreover, there was higher \%apoptosis (Fig. 6b) assessed via costaining of Hoechst33342/PI (Fig. 6c) in deferoxamine-pretreated H460 cells exposed with cisplatin compared with the cells treated with cisplatin alone. Taken together, these results indicated that cisplatininduced $\mathrm{OH}^{-}$activate survival autophagic response in lung cancer $\mathrm{H} 460$ cells.

\section{Cellular $\mathrm{OH}^{\cdot}$ regulate autophagy in human lung cancer H460 cells}

In order to link the effect of intracellular $\mathrm{OH}^{-}$formation on the autophagic response, an elevated cellular $\mathrm{OH}^{-}$level was generated in $\mathrm{H} 460$ cells by co-treatment with $\mathrm{H}_{2} \mathrm{O}_{2}(100 \mu \mathrm{M})$ and $\mathrm{FeSO}_{4}(50 \mu \mathrm{M})$, known as the Fenton reaction [30]. This resulted in a significant up-regulation of Atg7, Atg3, and LC3-II/LC3-I expression levels (Fig. 7a), while the protein level of p62 was decreased. The role of $\mathrm{OH}^{-}$in the regulation of autophagy in $\mathrm{H} 460$ cells was further confirmed through pretreatment with 1 $\mathrm{mM}$ deferoxamine for $30 \mathrm{~min}$, which was then removed, prior to exposed with co-treatment of $\mathrm{H}_{2} \mathrm{O}_{2}$ and $\mathrm{FeSO}_{4}$

\footnotetext{
(See figure on next page.)

Fig. 2 Autophagic response and the alteration of autophagy-related proteins in cisplatin-treated human lung cancer cells. a Expression level of the autophagic markers, LC3-II/LC3-I and p62, in H460 cells after culture with 50 MM cisplatin for 0-12 h, as evaluated by western blot analysis. b Densitometry analysis indicated that cisplatin up-regulated LC3-II/LC3-I and diminished p62 in a time-dependent manner. c Formation of autophagosomes and acidic autolysosomes were observed via the green fluorescence of monodansylcadaverine (MDC) and red fluorescence of acridine orange, respectively, after cisplatin treatment $(50 \mu \mathrm{M})$. Notably, staining with acridine orange indicates green fluorescence of cytoplasm and nucleolus while bright red/orange-red fluorescence of acridine orange represents acidic compartment. $\mathbf{d}$ Overexpression of Atg3 and Atg7 in lung cancer $\mathrm{H} 460$ cells after $12 \mathrm{~h}$ of cisplatin $(50 \mu \mathrm{M})$ treatment, as revealed by western blot analysis, without (e) any significant alteration in Atg5, Atg12, and Beclin-1 expression levels after $0-12 \mathrm{~h}$. Data are shown as the mean $\pm \mathrm{SD}(\mathrm{n}=3)$. ${ }^{*} p<0.05$ versus untreated control cells
} 

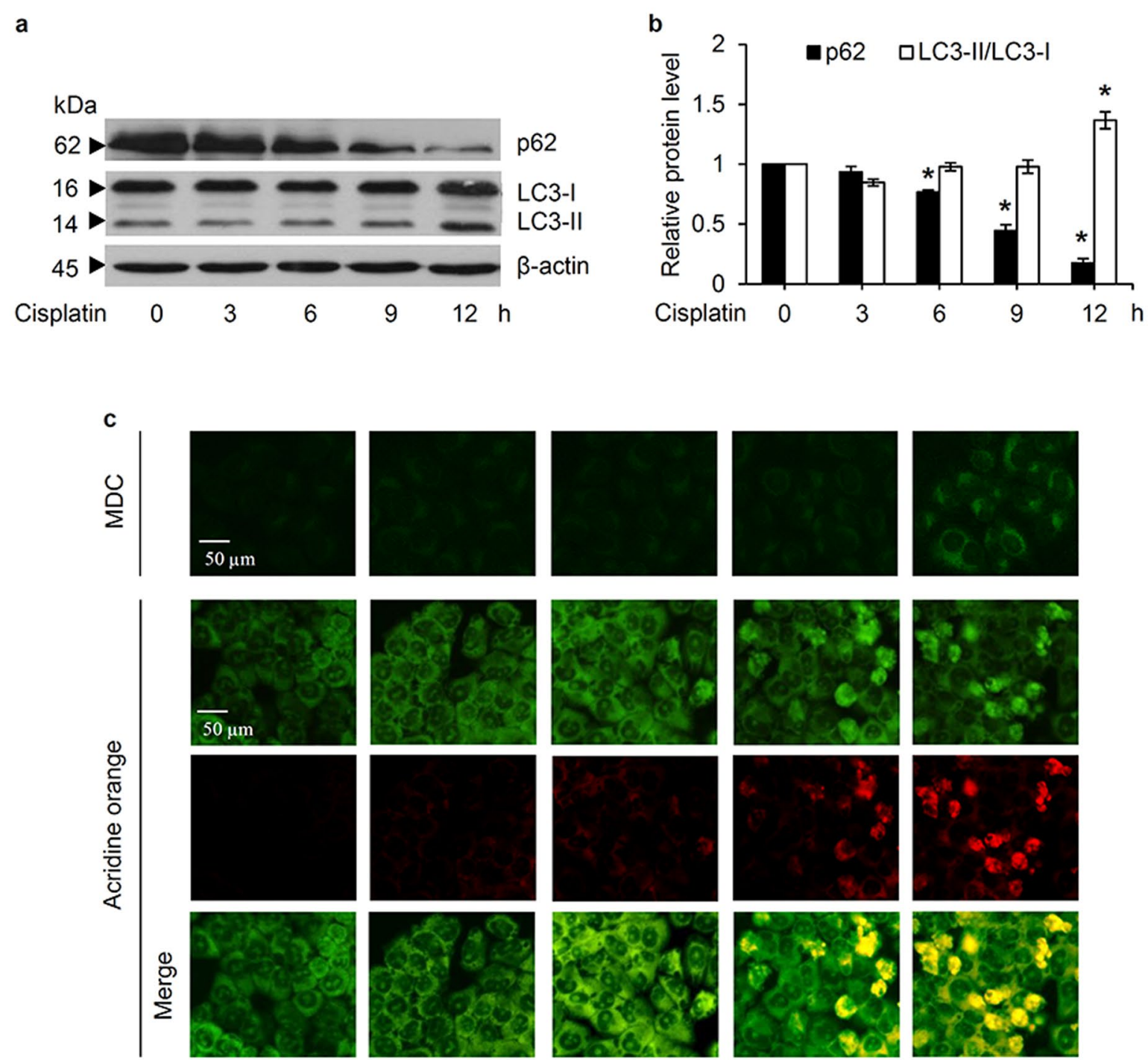

Cisplatin
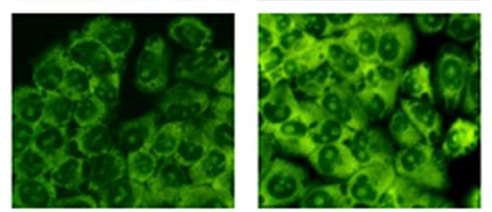

6
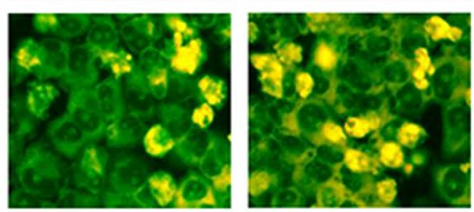

9

$12 \mathrm{~h}$

d

$$
\mathrm{kDa}
$$

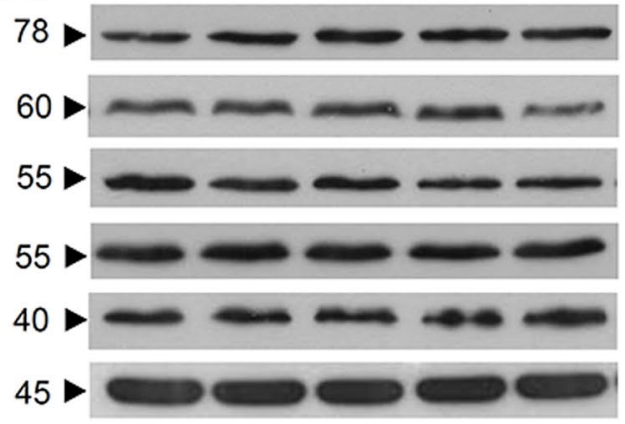

$\begin{array}{lllllll}\text { Cisplatin } & 0 & 3 & 6 & 9 & 12 \mathrm{~h}\end{array}$

Fig. 2 (See legend on previous page.) 

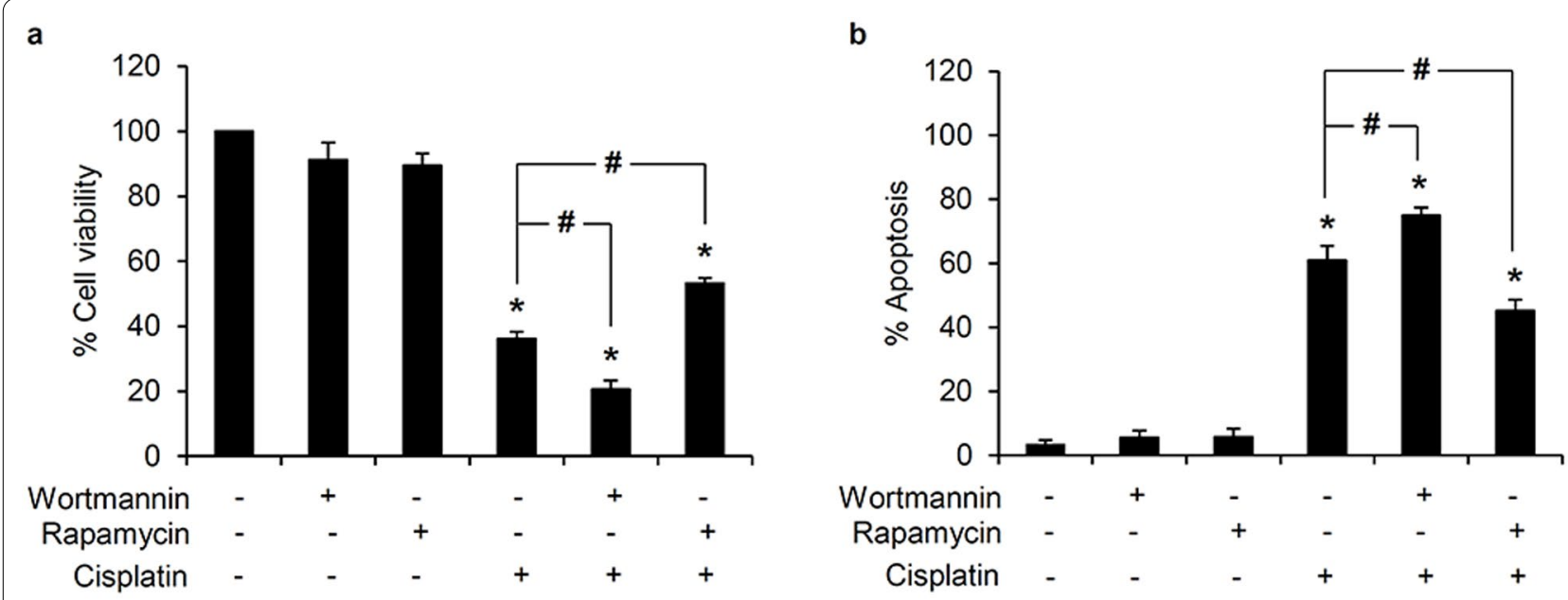

C
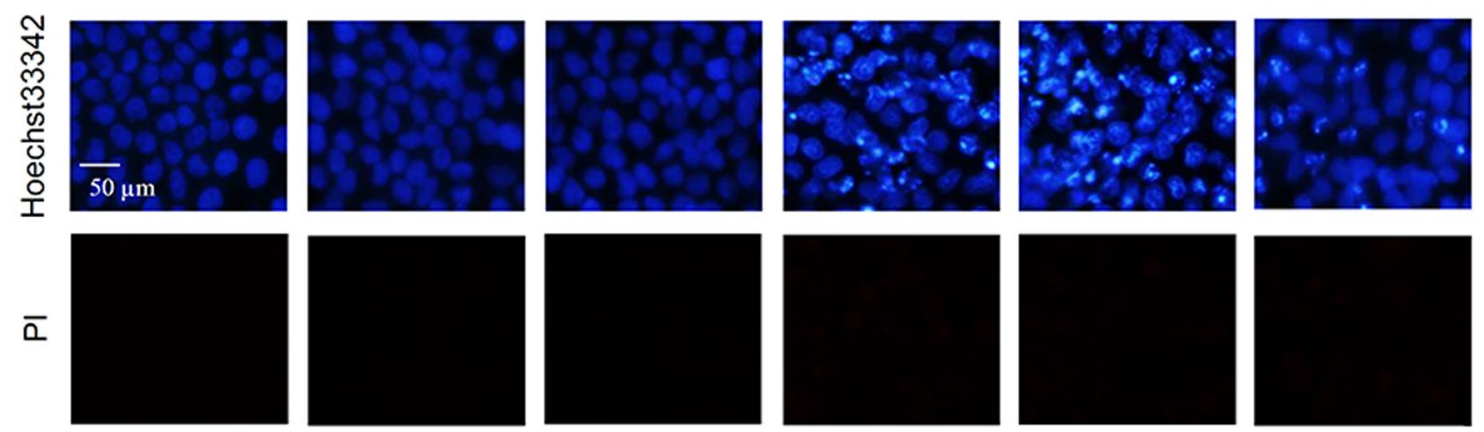

\section{Wortmannin \\ Rapamycin}

Cisplatin

Fig. 3 Protective role of autophagy against cisplatin-induced toxicity in human lung cancer cells. a Significant alteration of the relative cell viability was observed in $\mathrm{H} 460$ cells when pretreated with either $0.5 \mu \mathrm{M}$ wortmannin (autophagy inhibitor) or $100 \mathrm{nM}$ rapamycin (autophagy inducer) for $30 \mathrm{~min}$ followed by $50 \mu \mathrm{M}$ cisplatin for another $24 \mathrm{~h}$, compared with the cells only treated with cisplatin. $\mathbf{b}$ The percentage of apoptotic cells demonstrated that the inhibition of autophagy remarkably enhanced cisplatin-induced apoptosis, but (c) was inhibited, as evidenced with reduction of bright blue fluorescence of Hoechst33342, by pre-culture with rapamycin. Data are shown as the mean $\pm \operatorname{SD}(n=3)$. ${ }^{*} p<0.05$ versus untreated control cells. ${ }^{*} p<0.05$ versus only cisplatin-treated cells

to diminish generated cellular $\mathrm{OH}$, the protein levels of Atg7, Atg3, LC3-II/LC3-I, and p62 in the deferoxaminepretreated cells were not significantly different from the control cells not exposed to the Fenton reaction (Fig. 7b). Likewise, the MDC-labeled autophagosomes and red acridine orange-stained autolysosomes were augmented in $\mathrm{H} 460$ cells cultured with $\mathrm{H}_{2} \mathrm{O}_{2}$ and $\mathrm{FeSO}_{4}$ for $12 \mathrm{~h}$, while this was abrogated by deferoxamine pre-incubation (Fig. 7c).

\section{Discussion}

To escape from cell death, cancer cells mediate various responsive mechanisms to modulate their survival against chemotherapeutic agents. Among these survival signals, the autophagy has gained in attention [34]. This is a normal cellular defensive mechanism in response to various cellular stresses, such as nutrient deprivation, pathogen infection, and oxidative stress [35], which depends on the lysosomal degradation of damaged cellular organelles, misfolded/aggregated proteins, and harmful stimuli, by which autophagy efficiently promotes cell survival and restrains cell death $[16,36,37]$.

Cisplatin-based chemotherapy can prolong the survival of lung cancer patients at an advanced stage [38]. However, there is accumulating evidence of increasing chemo-resistance to this platinum-containing drug in lung cancer cells [7-11]. In order to impede cisplatinmediated cell death, cancer cells have adopted several 


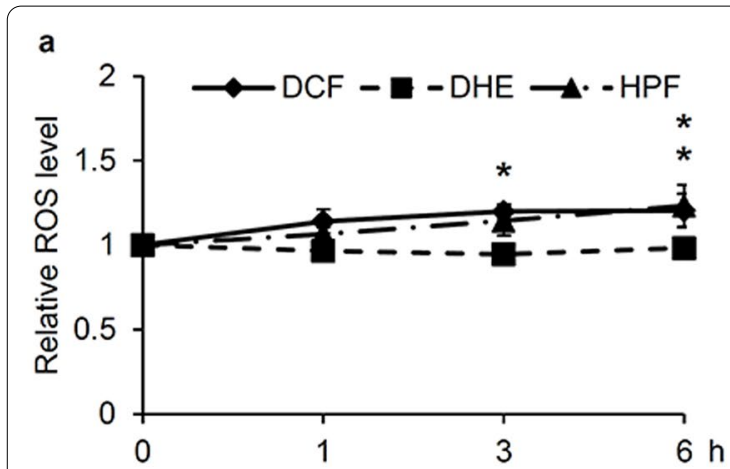

b
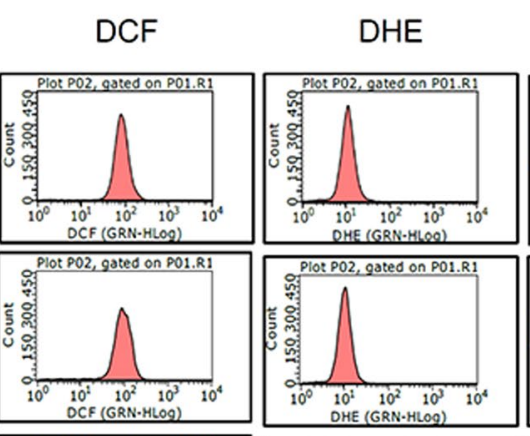

HPF
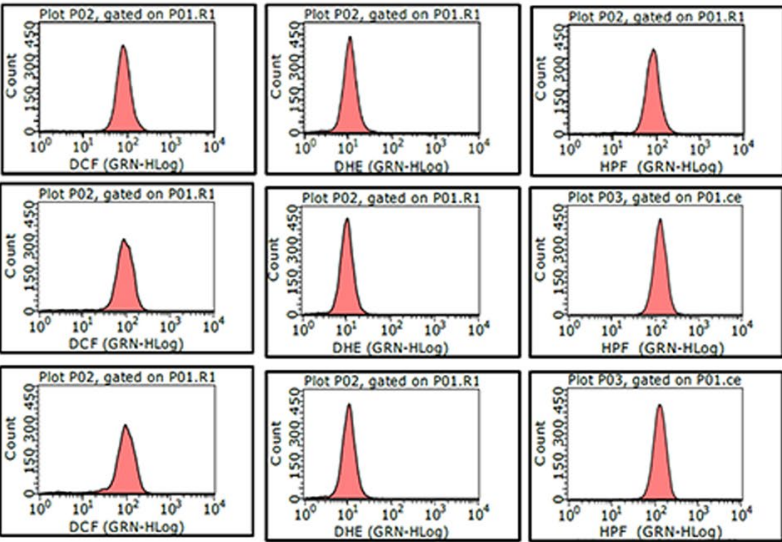

$\mathrm{Oh}$

c
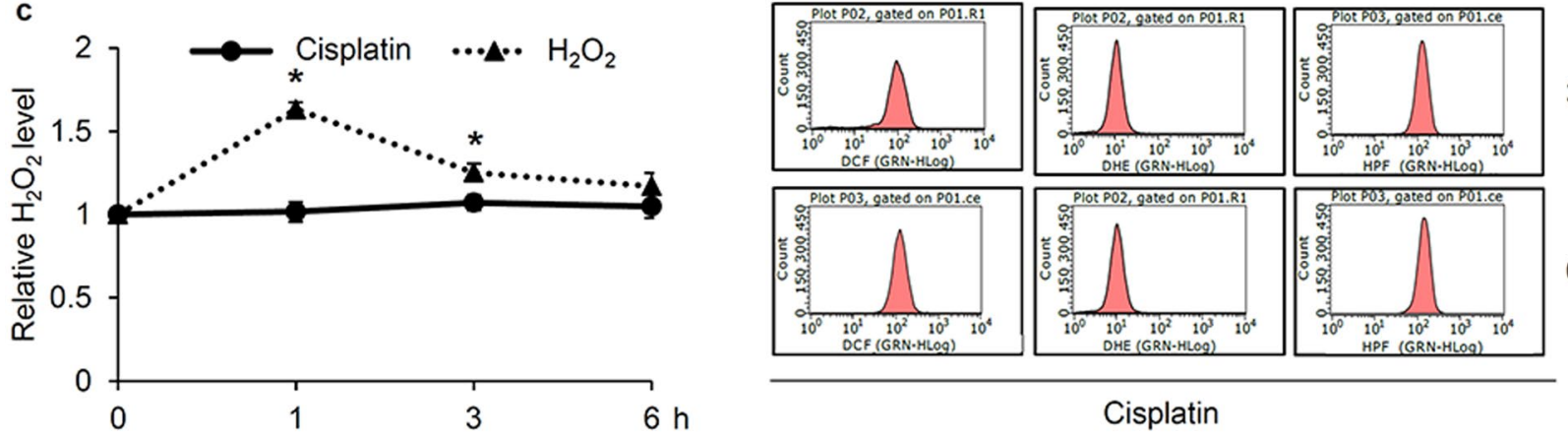

$3 \mathrm{~h}$

Cisplatin

Fig. 4 Elevated hydroxyl radicals in cisplatin-treated human lung cancer cells. a Augmented level of cellular ROS and hydroxyl radicals (OH) in lung cancer $\mathrm{H} 460$ cells after treatment with $50 \mu \mathrm{M}$ cisplatin for $6 \mathrm{~h}$, as determined by flow cytometric analysis with DCFH $\mathrm{H}_{2}$-DA and HPF, respectively, b without alteration of superoxide anions $\left(\mathrm{O}_{2}^{-}{ }^{-}\right.$) levels (flow cytometry chromatogram of DHE). c Detection with Amplex red clearly demonstrated the increased relative level of cellular hydrogen peroxide $\left(\mathrm{H}_{2} \mathrm{O}_{2}\right)$ in $\mathrm{H} 460$ cells after culture with $500 \mu \mathrm{M} \mathrm{H}_{2} \mathrm{O}_{2}$, but not by $50 \mu \mathrm{M}$ cisplatin. Data are shown as the mean $\pm S D(n=3)$. ${ }^{*} p<0.05$ versus untreated control cells

drug resistance mechanisms, such as modification of drug uptake/efflux, operation of cellular adduct tolerance, and alteration of apoptosis pathways $[39,40]$. Substantial evidence indicates that induction of an autophagic response induced by cisplatin also plays a critical role in the survival and drug resistance in various cancer cells $[13,16$, 41].

Likewise, in this study the treatment of lung cancer $\mathrm{H} 460$ cells with cisplatin at the maximal response concentration $(50 \mu \mathrm{M})$ clearly stimulated autophagy, as indicated by the conversion of LC3-I to LC3-II, formation of autophagosomes, and lysosomal degradation of the autophagic substrate, p62 (Fig. 2). Interestingly, pre-culture with an autophagy inhibitor, wortmannin, efficiently sensitized apoptosis in $\mathrm{H} 460$ cells treated with $50 \mu \mathrm{M}$ cisplatin (Fig. 3). These results strongly confirm a positive role for cisplatin-induced pro-survival autophagy in the chemotherapeutic resistance of human lung cancer cells. It should be noted that suppression on autophagic response could also be observed after cisplatin treatment depending on drug susceptibility. In cisplatin-sensitive cancer cells, cisplatin had been reported to mediate apoptosis through inhibition of autophagic survival mechanism [42].
Although DNA intercalation and ROS generation have been well established as cytotoxic mechanisms induced by cisplatin, modulation of the cellular redox status can activate survival signals in cisplatin-treated lung cancer cells $[43,44]$. It is worth noting that different species of ROS could be generated by cisplatin depending on the cisplatin concentration and cell type [29, 44, 45]. Detection of ROS with specific fluorescence probes revealed the gradual accumulation of $\mathrm{OH}^{\circ}$ in human lung cancer $\mathrm{H} 460$ cells cultured with $50 \mu \mathrm{M}$ cisplatin as early as $6 \mathrm{~h}$, while no alteration of $\mathrm{O}_{2}{ }^{--}$and $\mathrm{H}_{2} \mathrm{O}_{2}$ was noted (Fig. 4).

Oxidative stress has been demonstrated to mediate an autophagic response in different cell types [46-49]. In accord, the elimination of $\mathrm{OH}^{*}$ through pretreatment with the specific $\mathrm{OH}^{\prime}$ scavenger, deferoxamine, inhibited both the cisplatin- and Fenton reaction-mediated formation of autophagosomes and autolysosomes in human lung cancer cells (Figs. 5c and 7c). In addition, the autophagy markers (LC3-II/LC3-I and p62) and autophagy-regulating proteins (Atg3 and Atg7) were altered by increased cellular $\mathrm{OH}^{\circ}$, and abrogated by deferoxamine (Fig. 7a and b). This is the first report about the signaling molecules involving in $\mathrm{OH}^{-}$-mediating autophagy in human lung cancer cells. On the contrary, 
a

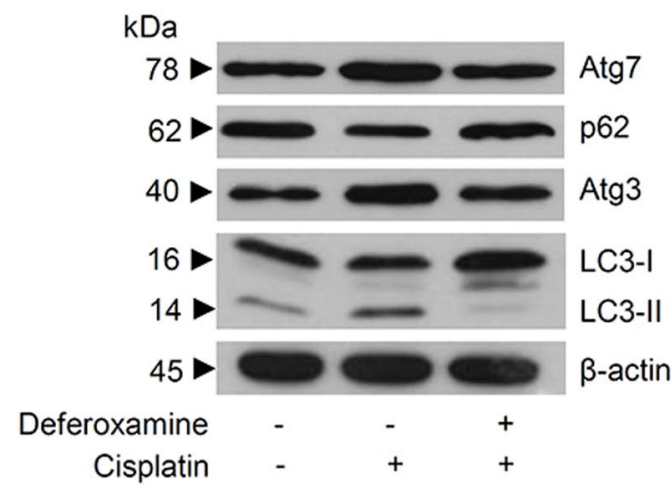

c b

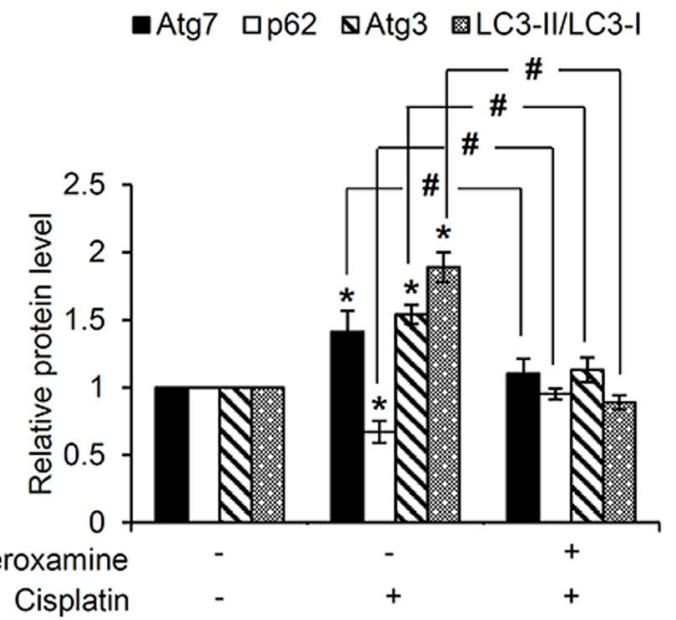

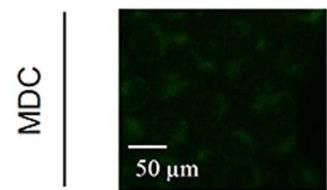
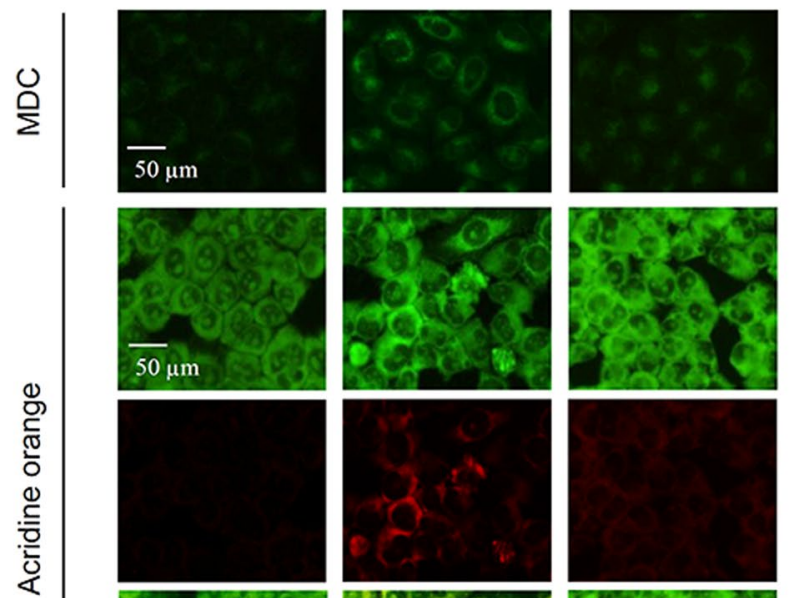

Ð
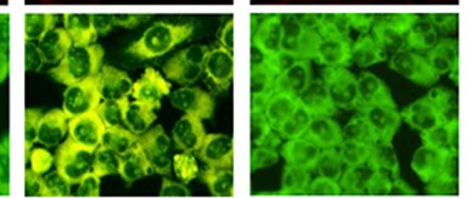

Deferoxamine

Cisplatin

Fig. 5 Cisplatin-induced hydroxyl radicals mediate autophagy in human lung cancer cells. a Pretreatment with the hydroxyl radical scavenger, deferoxamine (1 mM), reverted the alteration of autophagy-regulating proteins (Atg3 and Atg7) expression levels induced by cisplatin, as evidence by western blot analysis. $\mathbf{b}$ Significant increment in the LC3-II/LC3-I ratio, and increased Atg3 and Atg7 and decreased expression of p62 by cisplatin treatment was also abrogated by deferoxamine pretreatment. $\mathbf{c}$ Fluorescence microscopy demonstrated no accumulation of autophagosomes and autolysosomes, as detected by monodansylcadaverine (MDC) and acridine orange staining, respectively, in non-treated control and deferoxamine-pretreated cells. Notably, staining with acridine orange indicates green fluorescence of cytoplasm and nucleolus while bright red/ orange-red fluorescence of acridine orange represents acidic compartment. Data are shown as the mean $\pm \operatorname{SD}(n=3)$. ${ }^{*} p<0.05$ versus untreated control cells. ${ }^{p} p<0.05$ versus only cisplatin-treated cells

modulating on autophagy could in turn alter cellular redox status. As a cellular detoxifying mechanism, suppression of autophagy consequently elevating cellular ROS level is essential for apoptosis induction in lung cancer cells treated with low concentration of cisplatin [50].
In conformity with pro-survival autophagy modulated by $\mathrm{OH}$, resistance to cisplatin-induced cell death, as well as the overexpression of Atg3 and Atg7 in human lung cancer cells cultured with cisplatin was repressed 

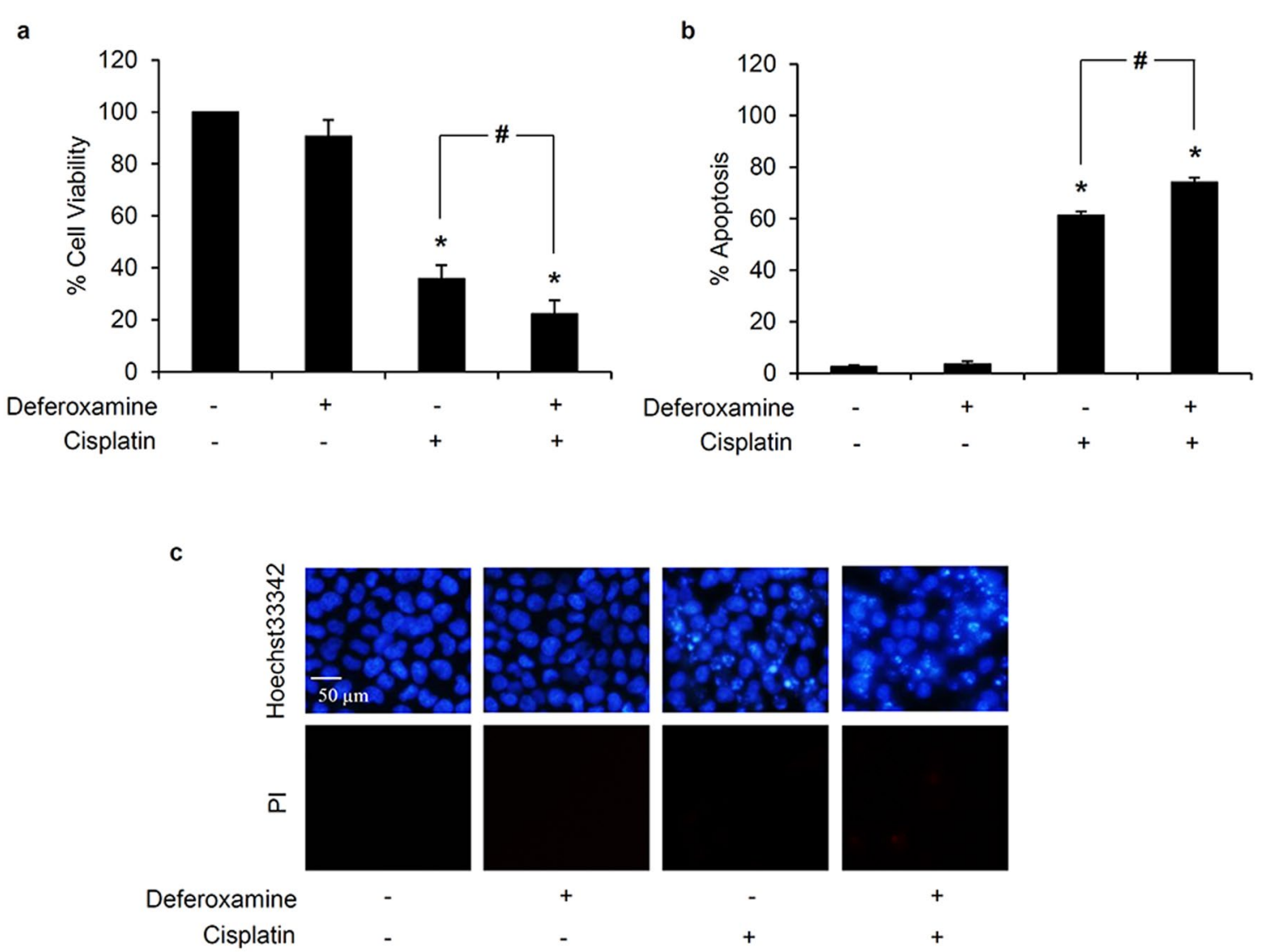

Fig. 6 Effect of hydroxyl radical scavenger on cisplatin-induced toxicity in human lung cancer cells. a Pretreatment with 1 mM deferoxamine, a hydroxyl radical scavenger, for 30 min prior exposure with $50 \mu \mathrm{M}$ cisplatin for $24 \mathrm{~h}$ significantly reduced cell viability in lung cancer $\mathrm{H} 460$ cells compared with the cells only treated with cisplatin. $\mathbf{b}$ The increment of percentage of apoptotic cells was remarkably observed in $\mathrm{H} 460$ cells pretreated with $1 \mathrm{mM}$ deferoxamine in response to cisplatin treatment. c Correspondingly, costaining with Hoechst33342/propidium iodide (PI) clearly demonstrated the accumulation of apoptotic cells presenting with bright blue fluorescence of Hoechst33342 without PI red fluorescence-stained necrotic cells in deferoxamine-pretreated $\mathrm{H} 460$ cells compared with both untreated control and only cisplatin treated cells. Data are shown as the mean $\pm S D(n=3) .{ }^{*} p<0.05$ versus untreated control cells. ${ }^{*} p<0.05$ versus only cisplatin-treated cells

by pre-incubation the cells with deferoxamine (Figs. 5a and $b$ and 6). These support the role of $\mathrm{OH}^{\circ}$ as a signaling molecule that triggers an autophagic response in cisplatin-treated lung cancer cells. Cisplatin was previously shown to generate autophagy in cancers through activation of Beclin-1 and Atg5, followed by the conversion of LC3-I to LC3-II [13, 51]. Although, the up-regulated level of Beclin-1, Atg5, and Atg12 were not observed in this study, there was also a significant increase of Atg3 and Atg7, which are essential factors for LC3-II formation, when $\mathrm{H} 460$ cells were incubated with cisplatin at $50 \mu \mathrm{M}$ (Fig. 2d and e). Moreover, the alteration of autophagic markers, autophagosome formation, and fusion of autophagosome-lysosome was sequentially found in the cisplatin-treated H460 cells (Fig. 2). Different regulatory pathways for autophagy in human lung cancer cells might result from diverse concentrations of cisplatin. Focusing on cisplatin-resistant lung cancer cells, the lowest concentration $(50 \mu \mathrm{M})$ that caused the highest level of apoptosis in the $\mathrm{H} 460$ cells was selected in this study, whereas previous studies on cisplatin-mediating autophagy in human lung cancer cells have used concentration at the half maximal inhibitory concentration $\left(\mathrm{IC}_{50}\right)$ or lower $[13,51]$.

It is the fact that various chemotherapeutic drugs, including doxorubicin have been shown to induce oxidative stress but the suppression on autophagic response is revealed. The accumulation of cellular ROS could be a consequence from the inhibition of autophagosome-lysosome fusion mediated by doxorubicin [52, 53]. Although $\mathrm{OH}^{*}$ are also generated through redox cycling of doxorubicin [54], whether these free radicals involve with autophagic response after doxorubicin treatment has not been thoroughly investigated. 
a

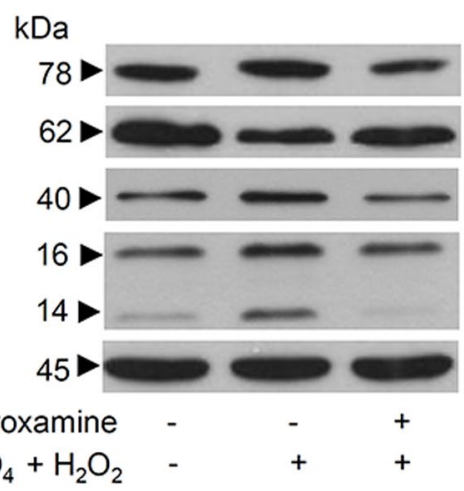

C
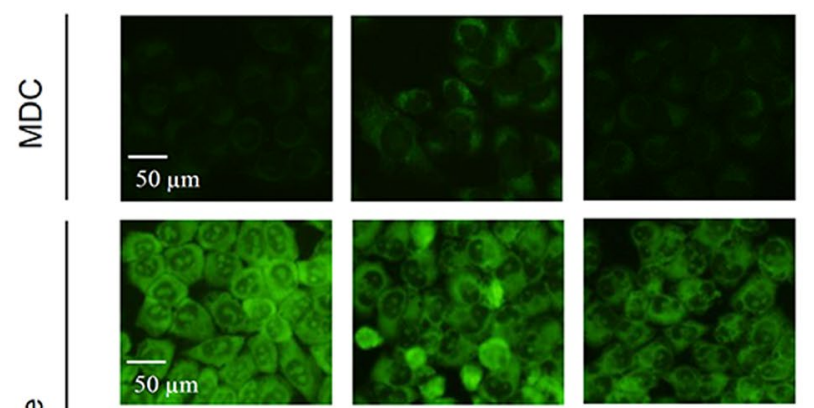

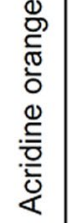
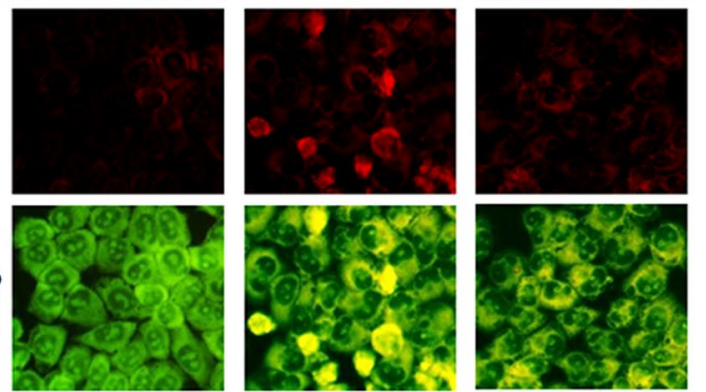

Deferoxamine

$\mathrm{FeSO}_{4}+\mathrm{H}_{2} \mathrm{O}_{2}$ b

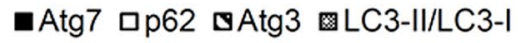

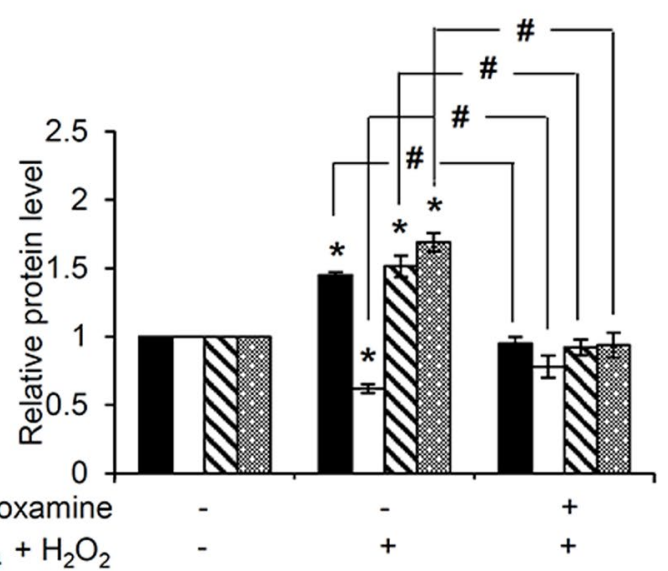

Fig. 7 Role of hydroxyl radicals in mediating the autophagic response in human lung cancer cells evidenced with (a) up-regulation of LC3-II/LC3-I, Atg3, and Atg7 expression levels, as detected by western blot analysis, after co-culture with $100 \mu \mathrm{M}$ hydrogen peroxide $\left(\mathrm{H}_{2} \mathrm{O}_{2}\right)$ and $50 \mu \mathrm{M}$ FeSO $\mathrm{O}_{4}$ for $12 \mathrm{~h}$, but (b) negated by pre-incubation with $1 \mathrm{mM}$ deferoxamine prior to exposure to $\mathrm{H}_{2} \mathrm{O}_{2}$ and $\mathrm{FeSO}_{4}$. (c) Autophagosome (green fluorescence of monodansylcadaverine (MDC)) and acidic autolysosome (red fluorescence of acridine orange) formation demonstrate the autophagy stimulating effect of hydroxyl radicals $(\mathrm{OH})$ generated by co-treatment of $\mathrm{H}_{2} \mathrm{O}_{2}(100 \mu \mathrm{M})$ and $\mathrm{FeSO}_{4}(50 \mu \mathrm{M})$ and its inhibition by deferoxamine pretreatment. Notably, staining with acridine orange indicates green fluorescence of cytoplasm and nucleolus while bright red/orange-red fluorescence of acridine orange represents acidic compartment. Data are shown as the mean $\pm \mathrm{SD}(\mathrm{n}=3) .{ }^{*} p<0.05$ versus untreated control cells. ${ }^{*} p<0.05$ versus $\mathrm{H}_{2} \mathrm{O}_{2}+\mathrm{FeSO}_{4}$-treated cells

\section{Conclusions}

The present study indicated that cisplatin at the maximum response concentration mediated autophagy through the induction of $\mathrm{OH}$; which subsequently activated Atg3 and Atg7 and led to apoptosis resistance in human lung cancer H460 cells (Fig. 8). Although the molecular mechanism of cisplatin driving pro-survival autophagy should be further investigated in other lung 
cancer cells both in in vitro and in vivo experiments, the primary information from this study would benefit for the development of novel strategies for chemotherapeutic treatment, especially in lung cancer.

\section{Methods}

\section{Chemical reagents}

Cisplatin, Actinomycin D, Hoechst33342, propidium iodide (PI), monodansylcadaverine (MDC), acridine orange, $2^{\prime}, 7^{\prime}$-dichloro-dihydro-fluorescein diacetate ester $\left(\mathrm{DCFH}_{2}-\mathrm{DA}\right)$, dihydroethidium (DHE), $3^{\prime}$-(p-hydroxyphenyl) fluorescein (HPF), deferoxamine, iron (II) sulfate heptahydrate $\left(\mathrm{FeSO}_{4} \cdot 7 \mathrm{H}_{2} \mathrm{O}\right), 30 \%(\mathrm{w} / \mathrm{w})$ hydrogen peroxide $\left(\mathrm{H}_{2} \mathrm{O}_{2}\right)$ solution, protease inhibitor cocktail, and skim milk powder were obtained from Sigma Chemical, Inc. (St. Louis, MO, USA). Dimethyl sulfoxide (DMSO) and bovine serum albumin (BSA) were bought from EMD Millipore corporation (Billerica, MA, USA), while 3-(4,5-dimethylthiazol-2-yl)-2,5-diphenyltetrazolium bromide (MTT) and Amplex ${ }^{\circledR}$ Red Hydrogen Peroxide/ Peroxidase Assay kit (A22188) were from Life Technologies (Eugene, OR, USA). Wortmannin, rapamycin, primary antibodies against Atg3, Atg5, Atg7, Atg12, Beclin-1, LC3, p62, and $\beta$-actin, and specific horseradish peroxidase (HRP)-linked secondary antibodies were acquired from Cell Signaling Technology, Inc. (Danver, MA, USA). Pierce ${ }^{\mathrm{TM}}$ Bicinchoninic acid (BCA) protein assay kit and SuperSignal ${ }^{\mathrm{TM}}$ West Pico PLUS Chemiluminescent Substrate for western blot analysis were provided by Thermo Fisher Scientific (Waltham, MA, USA).

\section{Cell culture}

Human lung cancer $\mathrm{H} 460$ cells (NCI-H460) were obtained from the American Type Culture Collection (ATCC; Manassas, VA, USA). They were grown in Roswell Park Memorial Institute (RPMI) medium supplemented with $10 \%$ fetal bovine serum, $2 \mathrm{mM} \mathrm{L}$-glutamine, and 100 units/mL penicillin/streptomycin (Gibco, Life Technologies, NY, USA) in a humidified atmosphere with $5 \% \mathrm{CO}_{2}$ at $37{ }^{\circ} \mathrm{C}$. Cells at $70-80 \%$ confluency (passage 20-40) were used for experiments.

\section{Cell viability assay}

Cell viability was evaluated by the surrogate MTT assay. Briefly, lung cancer cells were seeded at a density of $1 \times 10^{4}$ cells/well in 96-well plates for $12 \mathrm{~h}$. After the indicated treatment, the culture medium was replaced with $0.4 \mathrm{mg} / \mathrm{mL}$ of MTT solution and further incubated for $4 \mathrm{~h}$ at $37{ }^{\circ} \mathrm{C}$ in a dark place. After discarding the MTT solution, DMSO was added to dissolve the purple formazan crystals and the absorbance was read at $570 \mathrm{~nm}$ $\left(\mathrm{A}_{570}\right)$ using a microplate reader (Perkin Elmer, Turku, Finland). The relative cell viability (\%) was calculated from $100 \times$ the $\mathrm{A}_{570}$ ratio between the treated to nontreated control cells.

\section{Nuclear staining assay}

Costaining with Hoechst33342 and PI was performed to evaluate the mode of cell death. After treatment, H460 cells at a density of $1 \times 10^{4}$ cells/well in 96-well plates were incubated with $10 \mu \mathrm{M}$ Hoechst 33342 and $5 \mu \mathrm{g} / \mathrm{mL}$ PI for $30 \mathrm{~min}$ at $37{ }^{\circ} \mathrm{C}$. The cells were washed and then observed under an Olympus IX51 inverted fluorescence microscope (Olympus, Tokyo, Japan). Bright blue fluorescence of Hoechst33342 declares chromatin condensation and/or nuclei fragmentation in apoptotic cells, while the red fluorescence of PI indicates necrotic cell death [55]. The relative number of apoptotic cells to the total cell from three different observed areas was calculated and presented as the percentage apoptosis.

\section{Evaluation of autophagy formation}

Human lung cancer H460 cells were incubated with either $0.05 \mathrm{mM}$ MDC or $1 \mu \mathrm{M}$ acridine orange in phosphate buffer saline (PBS), pH 7.4 (Gibco, Life Technologies, NY, USA) for $15 \mathrm{~min}$ at $37{ }^{\circ} \mathrm{C}$ in the dark. Before examination under a fluorescence microscope (Olympus IX51, Tokyo, Japan), the staining solution was replaced with PBS. The MDC has been used as a specific dye to detect autophagosome formation [56], while the acidic cellular components of the autolysosome can be identified by the red fluorescence of acridine orange [57].

\section{Flow cytometry analysis of intracellular ROS}

The level of intracellular $\mathrm{ROS}, \mathrm{O}_{2}{ }^{-}$, and $\mathrm{OH}^{\circ}$ were determined via flow cytometry using the fluorescence probe $\mathrm{DCFH}_{2}$-DA, DHE, and HPF, respectively. For this, H460 cells at density of $3 \times 10^{5}$ cells/well were cultured overnight in a 6-well plate, then pre-incubated with $10 \mu \mathrm{M}$ of either $\mathrm{DCFH}_{2}$-DA, DHE, or HPF for $30 \mathrm{~min}$ at $4{ }^{\circ} \mathrm{C}$ in the dark before further culturing with $50 \mu \mathrm{M}$ cisplatin for $1-6 \mathrm{~h}$. The cells were then washed and resuspended in PBS prior to immediately analyzing for fluorescence intensity using a Guava easyCyte Benchtop Flow

(See figure on next page.)

Fig. 8 Schematic diagram summarizing the proposed mechanism of cisplatin-induced autophagy in human lung cancer H460 cells. Cisplatin elevates cellular hydroxyl radicals $(\mathrm{OH})$ with consequential activation of Atg3 and Atg7 and conversion of LC3-I to LC3-II. These result in the formation of autophagosomes and reduction of the autophagic substrate p62 through autophagosome-lysosome fusion, and eventually manifest the resistance to cisplatin-induced cell death in human lung cancer $\mathrm{H} 460$ cells. Red arrows indicate the modulation on autophagy related molecules induced by cisplatin 


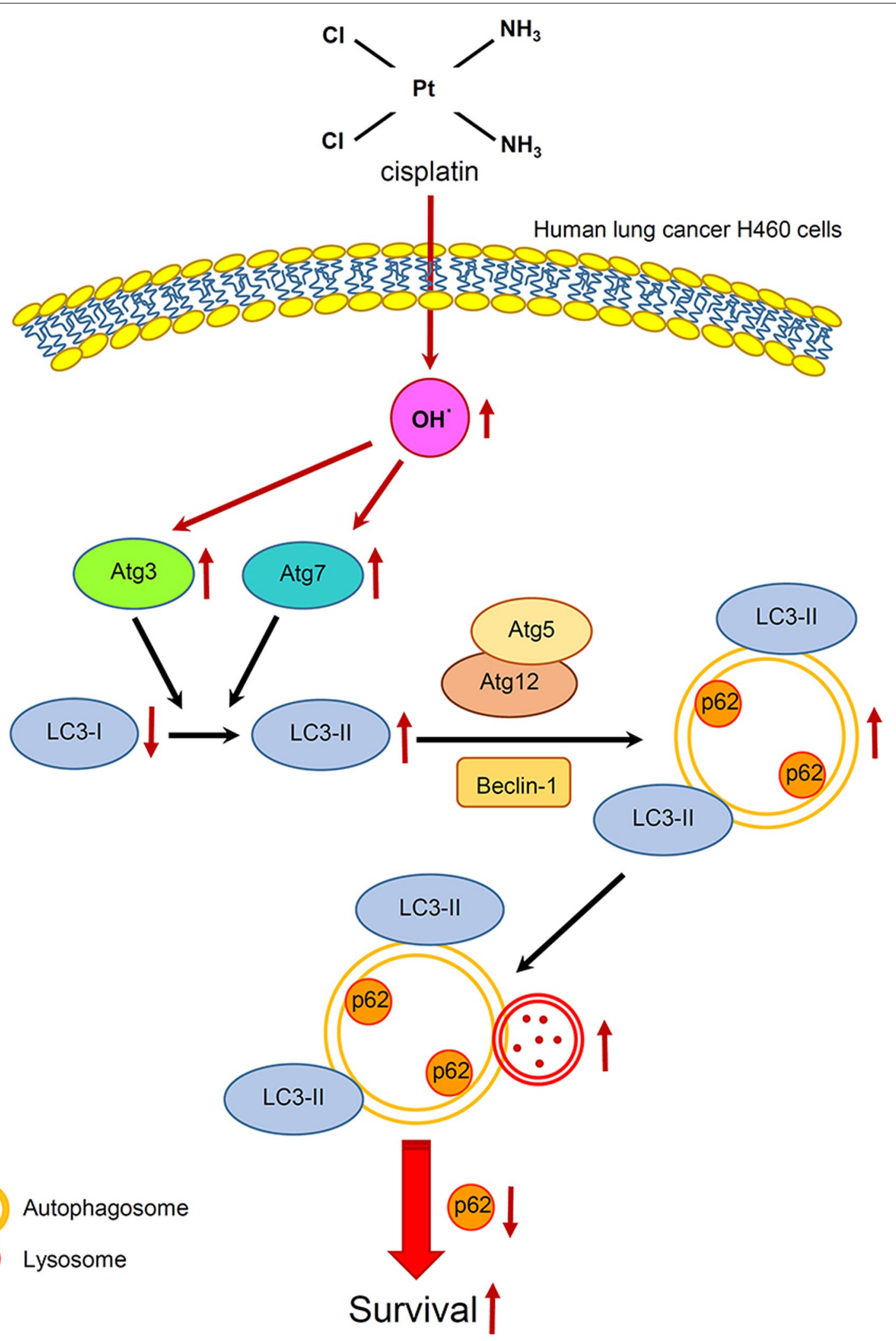

Fig. 8 (See legend on previous page.) 
Cytometer (EMD Millipore, Darmstadt, Germany) at an excitation/emission wavelength of 488/538, 488/610, and $490 / 515 \mathrm{~nm}$ for the detection of DCF, DHE, and HPF fluorescence intensity, respectively. The mean fluorescence intensity was quantified using the Guava InCyte version 3.1 software (EMD Millipore). The relative ROS level was derived from the fluorescence intensity ratio at the specific time point to that at $0 \mathrm{~h}$.

\section{Evaluation of cisplatin-induced hydrogen peroxide in human lung cancer cells}

Because of the permeability through the cell membrane, the extracellular $\mathrm{H}_{2} \mathrm{O}_{2}$ released from intracellular compartments can be detected by the specific fluorescence probe, Amplex red (10-acetyl-3,7-dihydroxyphenoxazine) [58-60]. For the assay, human lung cancer cells at a density of $1 \times 10^{4}$ cells/well were cultured in culture medium overnight in a 96-well plate and then cultured with either cisplatin $(50 \mu \mathrm{M})$ or $\mathrm{H}_{2} \mathrm{O}_{2}(500 \mu \mathrm{M})$ as a positive control for $30 \mathrm{~min}$. After washing with PBS, the cells were further incubated with $100 \mu \mathrm{L}$ of reaction mixture $(50 \mu \mathrm{M}$ Amplex red reagent and $0.1 \mathrm{U} / \mathrm{mL}$ HRP in Krebs-Ringer phosphate buffer). The fluorescence intensity was determined using a CLARIOstar microplate reader (BMG Labtech, Offenburg, Germany) at an excitation/emission wavelength of $545 / 590 \mathrm{~nm}$ for 1-6 h. The relative $\mathrm{H}_{2} \mathrm{O}_{2}$ level was calculated as the ratio of the fluorescence intensity at the specific time point to that at $0 \mathrm{~h}$.

\section{Western blot analysis}

After the specific treatment, human lung cancer cells were incubated with lysis buffer $(20 \mathrm{mM}$ Tris- $\mathrm{HCl}(\mathrm{pH}$ 7.5), $1 \%$ Triton $\mathrm{X}-100,150 \mathrm{mM}$ sodium chloride, $10 \%$ glycerol, $1 \mathrm{mM}$ sodium orthovanadate, $50 \mathrm{mM}$ sodium fluoride, $100 \mathrm{mM}$ phenylmethylsulfonyl fluoride, and a protease inhibitor cocktail) at $4{ }^{\circ} \mathrm{C}$ for $1 \mathrm{~h}$. The total cellular protein of the supernatant collected after centrifugation at $16,000 \mathrm{~g} \times 15 \mathrm{~min}\left(4{ }^{\circ} \mathrm{C}\right)$ was quantitated using a BCA protein assay kit. An equal amount of $35 \mu \mathrm{g}$ protein from each sample was resolved under denaturing conditions of sodium dodecylsulphate-polyacrylamide gel electrophoresis (12.5\% acrylamide resolving gel) and subsequently electro-transferred onto $0.45 \mu \mathrm{M}$ nitrocellulose membranes (Bio-Rad, Munich, Germany).

The transferred membranes were blocked for $1 \mathrm{~h}$ $\left(25{ }^{\circ} \mathrm{C}\right)$ in $5 \%$ non-fat dry milk in TBST $(25 \mathrm{mM}$ Tris$\mathrm{HCl} \mathrm{pH} \mathrm{7.5,} 125 \mathrm{mM} \mathrm{NaCl}$, and $0.05 \%$ Tween-20) at room temperature and incubated overnight with the specific primary antibody at $4{ }^{\circ} \mathrm{C}$. After washing three times (5 min) with TBST, the membranes were further incubated with the relevant HRP-conjugated secondary antibody for $2 \mathrm{~h}$ at $25^{\circ} \mathrm{C}$, and then detected using a chemiluminescence detection kit (Supersignal ${ }^{\mathrm{TM}}$ West Pico Plus) and quantified using the analyst/PC densitometry software (Bio-Rad). The intensity of each protein was normalized against that for the $\beta$-actin intensity and presented as the relative protein level compared to the non-treated control cells.

\section{Statistical analysis}

All data are presented as the mean \pm standard deviation (SD) from three independent experiments. The significance of differences among the groups were evaluated via one-way analysis of variance (ANOVA), followed by Turkey HSD post-hoc test using SPSS version 22. Statistical significance was defined as $p<0.05$.

\section{Abbreviations \\ Atg : Autophagy-related protein; BCA: Bicinchoninic acid; BSA: Bovine serum albumin; $\mathrm{DCFH}_{2}$-DA: 2',7'-dichloro-dihydro-fluorescein diacetate ester; DHE: Dihydroethidium; DMSO: Dimethyl sulfoxide; $\mathrm{FeSO}_{4} \cdot 7 \mathrm{H}_{2} \mathrm{O}$ : Iron (II) sulfate hep- tahydrate; HPF: 3'-(p-hydroxyphenyl) fluorescein; $\mathrm{H}_{2} \mathrm{O}_{2}$ : Hydrogen peroxide; HRP: Horseradish peroxidase; LC3-I: Microtubule-associated protein 1 light chain 3; LC3-II: Phosphatidylethanolamine conjugated form of microtubule- associated protein 1 light chain 3; MDC: Monodansylcadaverine; MTT: 3-(4,5-dimethylthiazol-2-yl)-2,5-diphenyltetrazolium bromide; $\mathrm{O}_{2}{ }^{-}$: Superox- ide anions; $\mathrm{OH}$ : Hydroxyl radicals; p62: Sequestosome 1; PI: Propidium iodide; PBS: Phosphate buffer saline; ROS: Reactive oxygen species; RPMI: Roswell Park Memorial Institute; SD: Standard deviation.}

\section{Acknowledgements}

SS would like to thank The 100th Anniversary Chulalongkorn University Fund for Doctoral Scholarship.

\section{Authors' contributions}

Conceived and designed the experiments: CC, PC. Performed the experiments: CC and SS. Analysis and interpretation of data: CC, EP and PC. Wrote the manuscript: CC and SS. All authors read and approved the final manuscript.

\section{Funding}

This research was funded by Ratchadaphiseksomphot Endowment Fund from Chulalongkorn University, Grant number CU_GR_62_20_33_01.

\section{Availability of data and materials}

All data generated or analyzed during this study are included in this article.

\section{Declarations}

Ethics approval and consent to participate

Not applicable.

Consent for publication

All the authors have read and approved the paper for publication.

\section{Competing interests}

The authors declare that they have no competing interests.

\section{Author details}

${ }^{1}$ Department of Biochemistry and Microbiology, Faculty of Pharmaceutical Sciences, Chulalongkorn University, 10330 Bangkok, Thailand. ${ }^{2}$ Department of Laboratory Medicine, Faculty of Medicine, Chulalongkorn University, 10330 Bangkok, Thailand. ${ }^{3}$ Center of Excellence in Vaccine Research and Development (Chula Vaccine Research Center- Chula VRC), Faculty of Medicine, Chulalongkorn University, 10330 Bangkok, Thailand. ${ }^{4}$ Department of Pharmacology and Physiology, Faculty of Pharmaceutical Sciences, 
Chulalongkorn University, 10330 Bangkok, Thailand. ${ }^{5}$ Cell-based Drug and Health Products Development Research Unit, Faculty of Pharmaceutical Sciences, Chulalongkorn University, 10330 Bangkok, Thailand.

Received: 28 October 2020 Accepted: 19 July 2021 Published online: 28 July 2021

\section{References}

1. Davies H, Bignell GR, Cox C, Stephens P, Edkins S, Clegg S, Teague J, Woffendin H, Garnett MJ, Bottomley W, Davis N, Dicks E, Ewing R, Floyd Y, Gray K, Hall S, Hawes R, Hughes J, Kosmidou V, Menzies A, Mould C, Parker A, Stevens C, Watt S, Hooper S, Wilson R, Jayatilake H, Gusterson BA, Cooper C, Shipley J, Hargrave D, Pritchard-Jones K, Maitland N, Chenevix-Trench G, Riggins GJ, Bigner DD, Palmieri G, Cossu A, Flanagan A, Nicholson A, Ho JW, Leung SY, Yuen ST, Weber BL, Seigler HF, Darrow TL, Paterson H, Marais R, Marshall CJ, Wooster R, Stratton MR. Futreal PA. Mutations of the BRAF gene in human cancer. Nature. 2002;417:949-54.

2. Bray F, Ferlay J, Soerjomataram I, Siegel RL, Torre LA, Jemal A. Global cancer statistics 2018: GLOBOCAN estimates of incidence and mortality worldwide for 36 cancers in 185 countries. CA Cancer J Clin. 2018;68:394-24.

3. Vansteenkiste J, De Ruysscher D, Eberhardt WE, Lim E, Senan S, Felip E, Peters S, ESMO Guidelines Working Group. Early and locally advanced non-small-cell lung cancer (NSCLC): ESMO Clinical Practice Guidelines for diagnosis, treatment and follow-up. Ann Oncol. 2013;24(Suppl 6):vi89-98.

4. Zappa C, Mousa SA. Non-small cell lung cancer: current treatment and future advances. Transl Lung Cancer Res. 2016;5:288-300.

5. Longley DB, Johnston PG. Molecular mechanisms of drug resistance. J Pathol. 2005;205:275-92.

6. Dasari S, Tchounwou PB. Cisplatin in cancer therapy: molecular mechanisms of action. Eur J Pharmacol. 2014;740:364-78.

7. Barr MP, Gray SG, Hoffmann AC, Hilger RA, Thomale J, O'Flaherty JD, Fennell DA, Richard D, O'Leary JJ, O'Byrne KJ. Generation and characterisation of cisplatin-resistant non-small cell lung cancer cell lines displaying a stem-like signature. PLoS One. 2013;8:e54193.

8. Kwok JM, Peck B, Monteiro LJ, Schwenen HD, Millour J, Coombes RC, Myatt SS, Lam EW. FOXM1 confers acquired cisplatin resistance in breast cancer cells. Mol Cancer Res. 2010;8:24-34.

9. Köberle B, Tomicic MT, Usanova S, Kaina B. Cisplatin resistance: preclinical findings and clinical implications. Biochim Biophys Acta. 2010;1806:172-82.

10. Leisching $G$, Loos $B$, Botha $M$, Engelbrecht AM. BCl-2 confers survival in cisplatin treated cervical cancer cells: circumventing cisplatin dosedependent toxicity and resistance. J Transl Med. 2015;13:328.

11. Kim SH, Ho JN, Jin H, Lee SC, Lee SE, Hong SK, Lee JW, Lee ES, Byun SS. Upregulated expression of BCL2, MCM7, and CCNE1 indicate cisplatinresistance in the set of two human bladder cancer cell lines: T24 cisplatin sensitive and T24R2 cisplatin resistant bladder cancer cell lines. Investig Clin Urol. 2016;57:63-72.

12. Wu HM, Jiang ZF, Ding PS, Shao LJ, Liu RY. Hypoxia-induced autophagy mediates cisplatin resistance in lung cancer cells. Sci Rep. 2015;5:12291.

13. Wu T, Wang MC, Jing L, Liu ZY, Guo H, Liu Y, Bai YY, Cheng YZ, Nan KJ, Liang $X$. Autophagy facilitates lung adenocarcinoma resistance to cisplatin treatment by activation of AMPK/mTOR signaling pathway. Drug Des Devel Ther. 2015:9:6421-31.

14. Sirichanchuen B, Pengsuparp T, Chanvorachote P. Long-term cisplatin exposure impairs autophagy and causes cisplatin resistance in human lung cancer cells. Mol Cell Biochem. 2012;364:11-8.

15. Wang J, Wu GS. Role of autophagy in cisplatin resistance in ovarian cancer cells. J Biol Chem. 2014:289:17163-73.

16. Lin JF, Lin YC, Tsai TF, Chen HE, Chou KY, Hwang TI. Cisplatin induces protective autophagy through activation of BECN1 in human bladder cancer cells. Drug Des Devel Ther. 2017;11:1517-33.

17. Lorin S, Hamaï A, Mehrpour M, Codogno P. Autophagy regulation and its role in cancer. Semin Cancer Biol. 2013;23:361-79.

18. Bao L, Jaramillo MC, Zhang Z, Zheng Y, Yao M, Zhang DD, Yi X. Induction of autophagy contributes to cisplatin resistance in human ovarian cancer cells. Mol Med Rep. 2015;11:91-8.
19. Cao QH, Liu F, Yang ZL, Fu XH, Yang ZH, Liu Q, Wang L, Wan XB, Fan XJ. Prognostic value of autophagy related proteins ULK1, Beclin 1, ATG3, ATG5, ATG7, ATG9, ATG10, ATG12, LC3B and p62/SQSTM1 in gastric cancer. Am J Transl Res. 2016;8:3831-47.

20. Xie Y, Kang R, Sun X, Zhong M, Huang J, Klionsky DJ, Tang D. Posttranslational modification of autophagy-related proteins in macroautophagy. Autophagy. 2015;11:28-45.

21. Nath S, Dancourt J, Shteyn V, Puente G, Fong WM, Nag S, Bewersdorf J, Yamamoto A, Antonny B, Melia TJ. Lipidation of the LC3/GABARAP family of autophagy proteins relies on a membrane-curvature-sensing domain in Atg3. Nat Cell Biol. 2014;16:415-24.

22. Bjørkøy G, Lamark T, Pankiv S, Øvervatn A, Brech A, Johansen T. Monitoring autophagic degradation of p62/SQSTM1. Methods Enzymol. 2009:452:181-97.

23. Zahri S, Razavi SM, Niri FH, Mohammadi S. Induction of programmed cell death by Prangos uloptera, a medicinal plant. Biol Res. 2009;42:517-22.

24. Paglin S, Hollister T, Delohery T, Hackett N, McMahill M, Sphicas E, Domingo D, Yahalom J. A novel response of cancer cells to radiation involves autophagy and formation of acidic vesicles. Cancer Res. 2001;61:439-44.

25. Wang H, Gao Z, Liu X, Agarwal P, Zhao S, Conroy DW, Ji G, Yu J, Jaroniec CP, Liu Z, Lu X, Li X, He X. Targeted production of reactive oxygen species in mitochondria to overcome cancer drug resistance. Nat Commun. 2018;9:562.

26. Liu Y, Li Q, Zhou L, Xie N, Nice EC, Zhang H, Huang C, Lei Y. Cancer drug resistance: redox resetting renders a way. Oncotarget. 2016;7:42740-61.

27. Cui Q, Wang JQ, Assaraf YG, Ren L, Gupta P, Wei L, Ashby CR Jr, Yang DH, Chen ZS. Modulating ROS to overcome multidrug resistance in cancer. Drug Resist Updat. 2018:41:1-25.

28. Wang L, Chanvorachote P, Toledo D, Stehlik C, Mercer RR, Castranova V, Rojanasakul Y. Peroxide is a key mediator of $\mathrm{BCl}-2$ down-regulation and apoptosis induction by cisplatin in human lung cancer cells. Mol Pharmacol. 2008;73:119-27.

29. Itoh T, Terazawa R, Kojima K, Nakane K, Deguchi T, Ando M, Tsukamasa Y, Ito $M$, Nozawa $Y$. Cisplatin induces production of reactive oxygen species via NADPH oxidase activation in human prostate cancer cells. Free Radic Res. 2011;45:1033-9.

30. Luanpitpong S, Nimmannit U, Chanvorachote P, Leonard SS, Pongrakhananon V, Wang L, Rojanasakul Y. Hydroxyl radical mediates cisplatin-induced apoptosis in human hair follicle dermal papilla cells and keratinocytes through $\mathrm{Bcl}-2$-dependent mechanism. Apoptosis. 2011;16:769-82.

31. Pullarkat V, Meng Z, Donohue C, Yamamoto VN, Tomassetti S, Bhatia R, Krishnan A, Forman SJ, Synold TW. Iron chelators induce autophagic cell death in multiple myeloma cells. Leuk Res. 2014;38:988-96.

32. Moon JH, Jeong JK, Park SY. Deferoxamine inhibits TRAIL-mediated apoptosis via regulation of autophagy in human colon cancer cells. Oncol Rep. 2015;33:1171-6.

33. Lan L, Wei W, Zheng Y, Niu L, Chen X, Huang D, Gao Y, Mo S, Lu J, Guo M, Liu Y, Lu B. Deferoxamine suppresses esophageal squamous cell carcinoma cell growth via ERK1/2 mediated mitochondrial dysfunction. Cancer Lett. 2018;432:132-43.

34. Housman G, Byler S, Heerboth S, Lapinska K, Longacre M, Snyder N, Sarkar S. Drug resistance in cancer: an overview. Cancers (Basel). 2014:6:1769-92.

35. Filomeni G, De Zio D, Cecconi F. Oxidative stress and autophagy: the clash between damage and metabolic needs. Cell Death Differ. 2015:22:377-88.

36. Chen L, Brewer MD, Guo L, Wang R, Jiang P, Yang X. Enhanced degradation of misfolded proteins promotes tumorigenesis. Cell Rep. 2017;18:3143-54.

37. Vera-Ramirez L, Vodnala SK, Nini R, Hunter KW, Green JE. Autophagy promotes the survival of dormant breast cancer cells and metastatic tumour recurrence. Nat Commun. 2018;9:1944.

38. de Castria TB, da Silva EM, Gois AF, Riera R. Cisplatin versus carboplatin in combination with third-generation drugs for advanced non-small cell lung cancer. Cochrane Database Syst Rev. 2013;8:CD009256.

39. Kartalou M, Essigmann JM. Mechanisms of resistance to cisplatin. Mutat Res. 2001;478:23-43. 
40. Cho HJ, Kim JK, Kim KD, Yoon HK, Cho MY, Park YP, Jeon JH, Lee ES, Byun SS, Lim HM, Song EY, Lim JS, Yoon DY, Lee HG, Choe YK. Upregulation of $\mathrm{BCl}-2$ is associated with cisplatin-resistance via inhibition of Bax translocation in human bladder cancer cells. Cancer Lett. 2006;237:56-66.

41. Long F, Liu W, Jia P, Wang H, Jiang G, Wang T. HIF-1 a-induced autophagy contributes to cisplatin resistance in ovarian cancer cells. Pharmazie. 2018;73:533-6.

42. Del Bello B, Toscano M, Moretti D, Maellaro E. Cisplatin-induced apoptosis inhibits autophagy, which acts as a pro-survival mechanism in human melanoma cells. PLoS One. 2013;8:e57236.

43. Cruz-Bermúdez A, Laza-Briviesca R, Vicente-Blanco RJ, García-Grande A, Coronado MJ, Laine-Menéndez S, Palacios-Zambrano S, Moreno-Villa MR, Ruiz-Valdepeñas AM, Lendinez C, Romero A, Franco F, Calvo V, Alfaro C, Acosta PM, Salas C, Garcia JM, Provencio M. Cisplatin resistance involves a metabolic reprogramming through ROS and PGC-1alpha in NSCLC which can be overcome by OXPHOS inhibition. Free Radic Biol Med. 2019;135:167-81.

44. Songserm T, Pongrakhananon V, Chanvorachote P. Sub-toxic cisplatin mediates anoikis resistance through hydrogen peroxide-induced caveolin-1 up-regulation in non-small cell lung cancer cells. Anticancer Res. 2012;32:1659-69.

45. Berndtsson M, Hägg M, Panaretakis T, Havelka AM, Shoshan MC, Linder S. Acute apoptosis by cisplatin requires induction of reactive oxygen species but is not associated with damage to nuclear DNA. Int J Cancer. 2007;120:175-80.

46. Scherz-Shouval R, Shvets E, Fass E, Shorer H, Gil L, Elazar Z. Reactive oxygen species are essential for autophagy and specifically regulate the activity of Atg4. EMBO J. 2019;38:e101812.

47. Chen Y, Azad MB, Gibson SB. Superoxide is the major reactive oxygen species regulating autophagy. Cell Death Differ. 2009;16:1040-52.

48. Gong K, Chen C, Zhan Y, Chen Y, Huang Z, Li W. Autophagy-related gene 7 (ATG7) and reactive oxygen species/extracellular signal-regulated kinase regulate tetrandrine-induced autophagy in human hepatocellular carcinoma. J Biol Chem. 2012;287:35576-88.

49. Lv W, Sui L, Yan X, Xie H, Jiang L, Geng C, Li Q, Yao X, Kong Y, Cao J. ROSdependent Atg4 upregulation mediated autophagy plays an important role in Cd-induced proliferation and invasion in A549 cells. Chem Biol Interact. 2018;279:136-44

50. Kaminskyy VO, Piskunova T, Zborovskaya IB, Tchevkina EM, Zhivotovsky B. Suppression of basal autophagy reduces lung cancer cell proliferation and enhances caspase-dependent and -independent apoptosis by stimulating ROS formation. Autophagy. 2012;8:1032-44.

51. Chen J, Zhang L, Zhou H, Wang W, LuO Y, Yang H, Yi H. Inhibition of autophagy promotes cisplatin-induced apoptotic cell death through
Atg5 and Beclin 1 in A549 human lung cancer cells. Mol Med Rep. 2018;17:6859-65.

52. Zhou X, Xu P, Dang R, Guo Y, Li G, Qiao Y, Xie R, Liu Y, Jiang P. The involvement of autophagic flux in the development and recovery of doxorubicin-induced neurotoxicity. Free Radic Biol Med. 2018;129:440-5.

53. Li DL, Wang ZV, Ding G, Tan W, Luo X, Criollo A, Xie M, Jiang N, May H, Kyrychenko V, Schneider JW, Gillette TG, Hill JA. Doxorubicin blocks cardiomyocyte autophagic flux by inhibiting lysosome acidification. Circulation. 2016;133:1668-87.

54. Zhu H, Sarkar S, Scott L, Danelisen I, Trush MA, Jia Z, Li YR. Doxorubicin redox biology: redox cycling, topoisomerase inhibition, and oxidative stress. React Oxyg Species (Apex). 2016;1:189-98.

55. Atale N, Gupta S, Yadav UC, Rani V. Cell-death assessment by fluorescent and nonfluorescent cytosolic and nuclear staining techniques. J Microsc. 2014;255:7-19.

56. Biederbick A, Kern HF, Elsässer HP. Monodansylcadaverine (MDC) is a specific in vivo marker for autophagic vacuoles. Eur J Cell Biol. 1995;66:3-14.

57. Murugan S, Amaravadi RK. Amaravadi, Methods for Studying Autophagy Within the Tumor Microenvironment. Adv Exp Med Biol. 2016;899:145-66.

58. Dębski D, Smulik R, Zielonka J, Michałowski B, Jakubowska M, Dębowska K, Adamus J, Marcinek A, Kalyanaraman B, Sikora A. Mechanism of oxidative conversion of Amplex(R) Red to resorufin: pulse radiolysis and enzymatic studies. Free Radic Biol Med. 2016;95:323-32.

59. Audi SH, Friedly N, Dash RK, Beyer AM, Clough AV, Jacobs ER. Detection of hydrogen peroxide production in the isolated rat lung using Amplex red. Free Radic Res. 2018;52:1052-62.

60. Fan JJ, Hsu WH, Hung HH, Zhang WJ, Lee YA, Chen KC, Chu CY, Ko TP, Lee MT, Lin CW, Cheng CH. Reduction in MnSOD promotes the migration and invasion of squamous carcinoma cells. Int J Oncol. 2019;54:1639-50.

\section{Publisher's Note}

Springer Nature remains neutral with regard to jurisdictional claims in published maps and institutional affiliations.

Ready to submit your research? Choose BMC and benefit from:

- fast, convenient online submission

- thorough peer review by experienced researchers in your field

- rapid publication on acceptance

- support for research data, including large and complex data types

- gold Open Access which fosters wider collaboration and increased citations

- maximum visibility for your research: over $100 \mathrm{M}$ website views per year

At BMC, research is always in progress.

Learn more biomedcentral.com/submissions 